\title{
The Zwitterionic Imidazolium Salt: First Used for Synthesis of 4-Arylidene-2-phenyl-5(4H)-oxazolones under Solvent-Free Conditions
}

\author{
Baocheng Zhou ${ }^{1,2}$ and Wenxing Chen ${ }^{2}$ \\ ${ }^{1}$ Department of Chemistry, Key Laboratory of Advanced Textile Materials and Manufacturing Technology, \\ Zhejiang Sci-Tech University, Hangzhou 310018, China \\ ${ }^{2}$ Key Laboratory of Advanced Textile Materials and Manufacturing Technology of Ministry of Education of China, \\ Zhejiang Sci-Tech University, Hangzhou 310018, China \\ Correspondence should be addressed to Wenxing Chen, chenwxg@yahoo.com.cn
}

Received 1 July 2012; Revised 22 October 2012; Accepted 23 October 2012

Academic Editor: Francisco José Hernández Fernández

Copyright (C) 2013 B. Zhou and W. Chen. This is an open access article distributed under the Creative Commons Attribution License, which permits unrestricted use, distribution, and reproduction in any medium, provided the original work is properly cited.

\begin{abstract}
The zwitterionic imidazolium salt was prepared and characterized by ${ }^{1} \mathrm{H}$ NMR. It was first used for synthesis of azlactones via Erlenmeyer synthesis from aromatic aldehydes and hippuric acid under solvent-free conditions. It was found that aldehyde substituents play an important role in these reactions. Better conversions and therefore higher isolated yields were observed when electron-withdrawing groups (EWG-) were present in the aromatic aldehyde. Opposite results were shown when electron-donating groups (EDG-) were present in the aromatic aldehyde. However, azlactones were obtained in moderate to high yields.
\end{abstract}

\section{Introduction}

4-Arylidene-2-phenyl-5(4H)-oxazolones are very important intermediates for the synthesis of a variety of bioactive molecules, fine chemicals, and precursors of several biologically active molecules such as amino acids and peptides [1]. These compounds are especially active as anticancer [2], antitumor [3], and inhibitors of central nervous system. Besides, these compounds are unique precursors for the synthesis of amino acids, peptides [4], heterocyclic compounds [5], and biosensor [6,7]. In fact, these precursors could be synthesized by Horner-Emmons, Heck, or ErlenmeyerPlÖchl [8] reactions followed by a complementary asymmetric hydrogenation reaction. The most common route to oxazolones involves the condensation of aromatic aldehydes and hippuric acid with a stoichiometric amount of fused sodium acetate in the presence of acetic anhydride as the dehydrating agent [9], such methodology is known as the Erlenmeyer-Plöchl reaction [1].

Since the first report on the synthesis of azlactones published in 1883, a number of catalysts have been developed in recent years. For example, lead acetate [10], $\mathrm{SO}_{3}$ in dimethylformamide [11], perchloric acid [12], polyphosphoric acid [13], carbodiimides [14], anhydrous zinc chloride [15], $\mathrm{Bi}(\mathrm{OAc})_{3}$ [16], $\mathrm{Bi}(\mathrm{OTf})_{3}$ [17], $\mathrm{Ca}(\mathrm{OAc})_{2}$ [18], KF-alumina [19], $\mathrm{Yb}(\mathrm{OTf})_{3}$ [20], $\mathrm{POCl}_{3}$ [21], $\mathrm{H}_{3} \mathrm{PW}_{12} \mathrm{O}_{40}$ [22], Sm [22], $\mathrm{RuCl}_{3}$ [22], $\mathrm{Al}_{2} \mathrm{O}_{3}$ [23], organic bases [1,24], $\mathrm{K}_{3} \mathrm{PO}_{4}$ [25], and organic-inorganic hybrid polyoxometalates [26] have been used to perform this condensation. However, some of these procedures have important drawbacks, such as the use of water-sensitive catalyst $[11,15,19]$, the use of noble metal/or salts as catalysts $[16,20,22]$, rigorous conditions [12, 21, 25], and the use of toxic reagents $[1,10,12,21,25]$. Additionally, many literatures $[15-23,26]$ show that the aldehydes bearing electron-donating groups (EDGs, such as $-\mathrm{NR}_{2},-\mathrm{NHR}$, $-\mathrm{NH}_{2},-\mathrm{OH},-\mathrm{OR},-\mathrm{OCOR}$, and $-\mathrm{CH}_{3}$ ) were more reactive than electron-withdrawing groups (EDGs, such as $-\mathrm{NO}_{2}$, $-\mathrm{CF}_{3},-\mathrm{CCl}_{3},-\mathrm{CN},-\mathrm{COOH},-\mathrm{CO}_{2} \mathrm{R}$, and $\left.-\mathrm{F}\right)$. Only few reports $[1,24,25]$ show opposite results. Then, there is a need for the development of environmentally benign methods, for example solvent-free condition, nontoxic reagents, mild reaction, simpler workup, and EDGs-active. 
<smiles>O=C(O)CNC(=O)c1ccccc1</smiles>

2<smiles>[R]c1ccc(C=O)cc1</smiles>

$3 e$

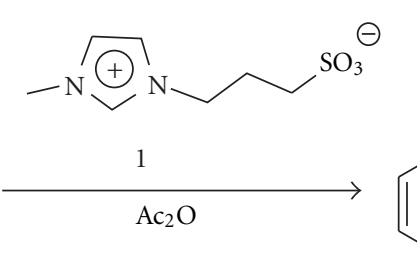

(l)

$4 \mathrm{e}$

$\mathrm{R}=4-\mathrm{N}\left(\mathrm{CH}_{3}\right)_{2}, 4-\mathrm{OCH}_{3}, 4-\mathrm{CH}_{3}, \mathrm{H}, 4-\mathrm{Cl}, 2-\mathrm{F}, 4-\mathrm{CF}_{3}, 4-\mathrm{NO}_{2}$<smiles>O=Cc1ccc2c(c1)OCO2</smiles>

$3 b$<smiles>O=Cc1ccco1</smiles>

$3 \mathbf{j}$

Scheme 1: The zwitterionic imidazolium salt (1) catalyzed the Erlenmeyer reaction.

Recently, Rostami has reported a new organic-inorganic hybrid polyoxometalates for the catalytic ErlenmeyerPlöchl reaction involved using $[\mathrm{bmim}]_{3} \mathrm{PW}_{12} \mathrm{O}_{40}$ and [bmim $]_{4} \mathrm{~W}_{10} \mathrm{O}_{32}$ as catalysts [26]. They found that the ion identity has an important impact on its property, and the introduction of [bmin] ion resulting more efficient than that of the others (such as $\mathrm{K}^{+}$). Furthermore, the using of $\mathrm{PW}_{12} \mathrm{O}_{40}{ }^{3-}$ and $\mathrm{W}_{10} \mathrm{O}_{32}{ }^{4-}$ will cause environmental problems. Besides, the aldehydes bearing electron-donating groups (EDGs) were given higher product yield and short time. Recently, zwitterionic salts have become research topic due to high ion density and high matrix mobility at ambient temperature [27]. Hajra has recently reported that zwitterionic-type molten salt may act as a bifunctional organocatalyst in the aza-Henry reaction [28] and for synthesis of 2-amidoalkyl and 2-carbamatoalkyl naphthols [29]. The imidazolium salt (1) contained [bmim] as cation and sulfonate as anion by covalent binding. According to [26], we want to know whether the introduction of sulfonate as anion instead of $\mathrm{PW}_{12} \mathrm{O}_{40}{ }^{3-}$ and $\mathrm{W}_{10} \mathrm{O}_{32}{ }^{4-}$ could impact on its catalytic property. Interested in this question and our continual research in the Erlenmeyer reaction [20], we report here the preparation, characterization, and catalytic activity of the imidazolium salt (1) in the catalyzed Erlenmeyer reaction for synthesis of azlactones under solvent-free conditions (Scheme 1).

\section{Results and Discussion}

The imidazolium salt (1) was synthetized [27] and characterized by ${ }^{1} \mathrm{H}$ NMR. In order to evaluate the catalytic activity of sulfonate, several sulfonates such as imidazolium salt (1), methanesulfonic acid, and sulfamic acid were tested in the Erlenmeyer reaction. The results are reported in Table 1. It was found that imidazolium salt (1) (Table 1, entry 1) provided azlactone $\mathbf{4 e}$ in the highest isolated yield in very simple procedure and was therefore selected for further study.
TABLE 1: Evaluation of several sulfonates in the Erlenmeyer reaction.

\begin{tabular}{lcccc}
\hline Entry & Catalyst & $\begin{array}{c}\text { Reaction } \\
\text { temperature } \\
\left({ }^{\circ} \mathrm{C}\right)\end{array}$ & $\begin{array}{c}\text { Reaction } \\
\text { time } \\
(\mathrm{h})\end{array}$ & $\begin{array}{c}\text { Isolated } \\
\text { yields } \\
(\%)^{\mathrm{a}}\end{array}$ \\
\hline 1 & Imidazolium salt $(\mathbf{1})$ & 60 & 4 & 76 \\
2 & $\mathrm{CH}_{3} \mathrm{SO}_{3} \mathrm{H}$ & 60 & 4 & 16 \\
3 & $\mathrm{NH}_{2} \mathrm{SO}_{3} \mathrm{H}$ & 60 & 4 & 7 \\
\hline
\end{tabular}

${ }^{a}$ Based on benzaldehyde; isolated yields based on benzaldehyde; $5 \mathrm{mmol}$ benzaldehyde, $5.5 \mathrm{mmol}$ hippuric acid, $10 \mathrm{mmol} \%$ catalyst, and $15 \mathrm{mmol}$ acetic anhydride were used.

The overall process defined as the Erlenmeyer reaction was initially studied using benzaldehyde $\mathbf{3 e}$ as the substrate (Table 2). As shown in Table 2, different conditions have been conducted such as the amount catalyst, temperature, and reaction time. The amounts of textbf 1 were tested, and it was found that $5 \mathrm{mmol} \%$ of $\mathbf{1}$ was enough to accomplish the reaction (Table 2, entries 2-5) when $10 \mathrm{mmol} \%$ of stoichiometric amount were required as previously reported. Increasing the amount of catalyst did not obviously improve the yield. Besides, 2-phenyloxazol-5-one was found as byproduct when used without catalyst in the reaction which was in accordance with [23]. 2-phenyloxazol-5-one was proved as important intermediate in the Erlenmeyer reaction. Similarly, reaction temperature and time were also investigated. The isolated yield was low (15\%, Table 2, entry 6) as the condensation of hippuric acid to 2-phenyloxazol-5-one needs high temperature. However, some unknown by-products were formed when reaction temperature heated up to reflux temperature and caused lower yield than the yield in $60^{\circ} \mathrm{C}$. In the reflux temperature, heavy slurry was found causing initial reactor agitation problems and an extended process reaction time [24]. It was found that four hours seem to be the optimum reaction time as shown in Table 2 (entries 10-13). Extended time was not available to higher yield (Table 2, entry 13). 


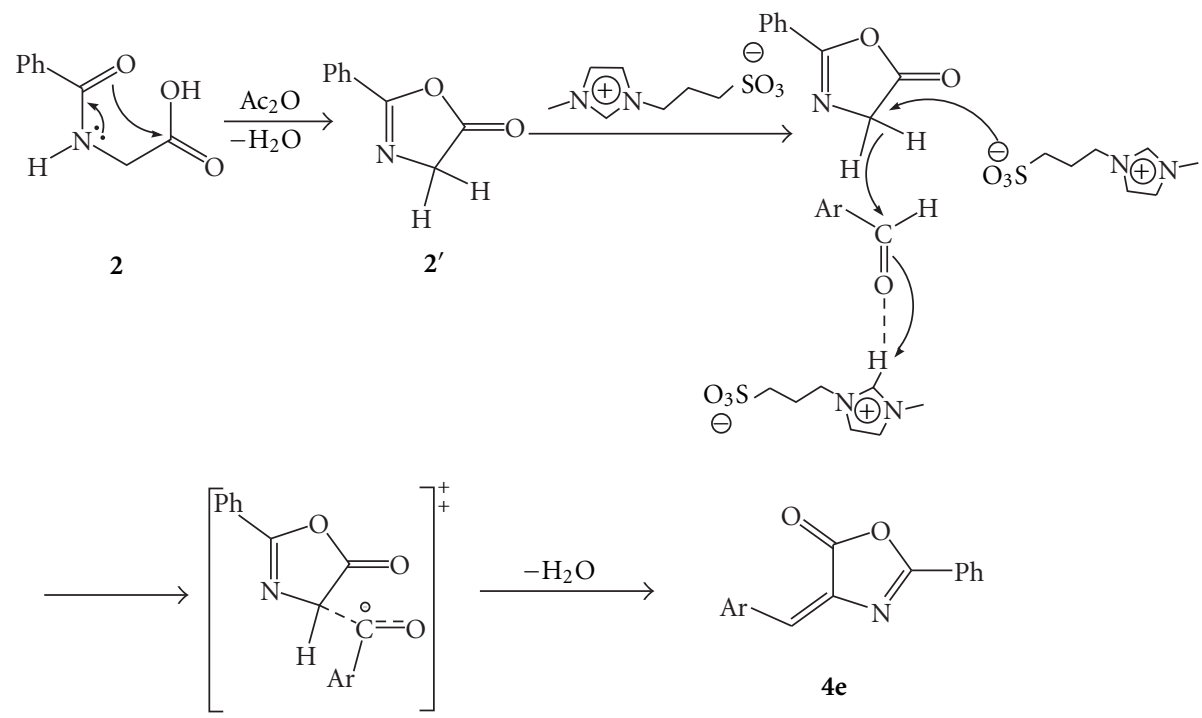

SCHEME 2: A plausible reaction mechanism.

TABLE 2: Reaction conditions in the Erlenmeyer reaction.

\begin{tabular}{lcccc}
\hline Entry & $\begin{array}{c}\text { The amount } \\
\text { of catalysts } \\
(\mathrm{mmol} \%)\end{array}$ & $\begin{array}{c}\text { Reaction } \\
\text { temperature } \\
\left({ }^{\circ} \mathrm{C}\right)\end{array}$ & $\begin{array}{c}\text { Reaction time } \\
(\mathrm{h})\end{array}$ & $\begin{array}{c}\text { Isolated yields } \\
(\%)^{\mathrm{a}}\end{array}$ \\
\hline 1 & 0 & 60 & 4 & $41^{\mathrm{b}}$ \\
2 & 2.5 & 60 & 4 & 67 \\
3 & 5 & 60 & 4 & 75 \\
4 & 10 & 60 & 4 & 76 \\
5 & 20 & 60 & 4 & 78 \\
6 & 5 & 25 & 24 & 15 \\
7 & 5 & 40 & 4 & 56 \\
8 & 5 & 60 & 4 & 75 \\
9 & 5 & Reflux & 4 & 62 \\
10 & 5 & 60 & 1.5 & 53 \\
11 & 5 & 60 & 2.5 & 56 \\
12 & 5 & 60 & 4 & 75 \\
13 & 5 & 60 & 5 & 75 \\
\hline
\end{tabular}

${ }^{a}$ Based on benzaldehyde; isolated yields based on benzaldehyde; $5 \mathrm{mmol}$ benzaldehyde, $5.5 \mathrm{mmol}$ hippuric acid and $15 \mathrm{mmol}$ acetic anhydride were used.

${ }^{\mathrm{b}}$ Not isolated yield, some by-products were found.

To explore the scope of our catalyst, a wide variety of aldehydes were investigated in this system including aromatic and aliphatic aldehdyes (Table 3, entries 1-12). Unfortunately, aliphatic aldehyde cannot be activated in this system (Table 3, entries 11-12). Interestingly, aromatic aldehyes with the electron-withdrawing groups (EWG) were present more active than that of opposite aldehydes (Table 3, entries 1-9). EDG aldehydes resulted in lower conversion and longer reaction time. Similar phenomenon was only mentioned by Thomas's research group [1, 24, 25]. Compared to the previous report [26], it was thought that the existence of [bmin] made high catalyst activity of $[\mathrm{bmim}]_{3} \mathrm{PW}_{12} \mathrm{O}_{40}$ and $[\mathrm{bmim}]_{4} \mathrm{~W}_{10} \mathrm{O}_{32}$. According to this theory and our research, it can be deduced that the existence of sulfonate may cause the different electronic effect, and a supposed reaction mechanism was given $[28,29]$ in Scheme 2. 2phenyloxazol-5-one ( $\left.2^{\prime}\right)$ was first generated in condensation reaction which happened in the presence of acetic anhydride as the dehydrating agent. The imidazolium salt could activate both aldehydic carbonyl oxygen and acidic hydrogen of 2phenyloxazol-5-one ( $\mathbf{2}^{\prime}$ ). The zwitterionic imidazolium salt (1) may act as a bifunctional organocatalyst in this reaction. The electrophilic activation of the aldehyde carbonyl is expected to take place through hydrogen bond formation with C-2 hydrogen atom of the imidazolium moiety. Similar mechanisms were indicated in the aza-Henry reaction [28] and aza-Michael addition [29].

\section{Conclusions}

In summary, imidazole-based zwitterionic-type molten salts are a new class of catalyst for the synthesis of 4-arylidene-2phenyl-5(4H)-oxazolones through the Erlenmeyer reaction under solvent-free conditions. This present procedure is equally effective in aryl aldehydes with electron-withdrawing groups. The nonhazardous experimental conditions, ease of reaction, short reaction times, high yields, and metal-free catalyst are the notable advantages of this procedure. To the best of our knowledge, this is the first report of the Erlenmeyer reaction, promoted by a zwitterionic imidazolium salt under solvent-free conditions. The investigation of the mechanism of this reaction and the use of chiral zwitterions are underway and will be reported in due course. Thus, it provides a better and more practical alternative to the existing methodologies. 
TABLE 3: Preparation of azlactones from different aldehydes.

\begin{tabular}{|c|c|c|c|c|c|c|}
\hline Entry & R (aldehyde) & Reaction time (h) & Azlactones & 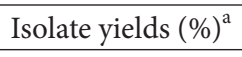 & Mp found $\left({ }^{\circ} \mathrm{C}\right)$ & Mp lit. $\left({ }^{\circ} \mathrm{C}\right)$ \\
\hline 1 & $4-\mathrm{N}\left(\mathrm{CH}_{3}\right)_{2}$ & 5.5 & $4 a$ & 70 & $211-213$ & $214[25]$ \\
\hline 2 & Heliotropin & 5 & $4 b$ & 67 & $197-199$ & $199[30]$ \\
\hline 3 & $4-\mathrm{OCH}_{3}$ & 5 & $4 c$ & 62 & $155-156$ & 159 [25] \\
\hline 4 & $4-\mathrm{CH}_{3}$ & 6 & $4 d$ & 40 & $143-144$ & 144 [25] \\
\hline 5 & $\mathrm{H}$ & 4 & $4 e$ & 75 & $168-169$ & $166[25]$ \\
\hline 6 & $4-\mathrm{Cl}$ & 5.5 & $4 f$ & 82 & $196-197$ & $196[25]$ \\
\hline 7 & $2-\mathrm{F}$ & 4 & $4 g$ & 55 & $166-167$ & $168[31]$ \\
\hline 8 & $4-\mathrm{CF}_{3}$ & 3 & $4 h$ & 85 & $173-174$ & $174[32]$ \\
\hline 9 & $4-\mathrm{NO}_{2}$ & 3 & $4 i$ & 89 & $240-241$ & $239[25]$ \\
\hline 10 & 2-Furaldehyde & 5 & $4 j$ & 35 & $170-172$ & $169[25]$ \\
\hline 11 & Isobutyraldehyde & 5 & - & $\mathrm{ND}^{\mathrm{b}}$ & - & - \\
\hline 12 & 3-Phenylpropionaldehyde & 5 & - & $\mathrm{ND}^{\mathrm{b}}$ & - & - \\
\hline
\end{tabular}

${ }^{a}$ Based on aldehyde; isolated yields based on aldehyde; $5 \mathrm{mmol}$ aldehyde, $5.5 \mathrm{mmol}$ hippuric acid, $5 \mathrm{mmol} \%$ imidazolium salt (1), and $15 \mathrm{mmol}$ acetic anhydride were used; the reaction was carried out at $60^{\circ} \mathrm{C}$.

${ }^{\mathrm{b}}$ No product was detected.

\section{Experimental}

4.1. Materials. All chemicals and solvents were obtained from commercial sources and used without further purification. Melting points were recorded on $\mathrm{X}_{4}$ micro- melting apparatus and uncorrected. FT-IR spectra were recorded using $\mathrm{KBr}$ pellets on a Nicolet Avatar Spectrophotometer. ${ }^{1} \mathrm{H}$ NMR spectra were recorded on a Bruker Avance DMX 400 instrument using $\mathrm{CDCl}_{3}$ and DMSO- $\mathrm{d}_{6}$ as the solvents with TMS as an internal standard. Mass spectra were measured with an HP 5903 mass spectrometer with $70 \mathrm{eV}$ energy.

4.2. Synthesis of Imidazolium Salt (1) [27]. 1-methyimidazole $(3.28 \mathrm{~g}, 40 \mathrm{mmol})$ was dissolved in acetone $(80 \mathrm{~mL})$, and $40 \mathrm{~mL}$ of 1,3-propanesultone $(4.88 \mathrm{~g}, 40 \mathrm{mmol})$ in acetone were added slowly at $0^{\circ} \mathrm{C}$. Mixtures were stirred at room temperature for 5 days in a dry $\mathrm{N}_{2}$ atmosphere. The precipitate was recovered and washed by filtration and dried in vacuo at $60^{\circ} \mathrm{C}$. White solid; ${ }^{1} \mathrm{H}$ NMR $\left(400 \mathrm{MHz}, \mathrm{DMSO}-\mathrm{d}_{6}\right) \delta=2.09$ $\left(\mathrm{t}, 2 \mathrm{H}, J=7.0 \mathrm{~Hz}, \mathrm{CH}_{2}\right), 2.45\left(\mathrm{t}, 2 \mathrm{H}, J=11.3 \mathrm{~Hz}, \mathrm{CH}_{2}\right), 3.85$ $\left(\mathrm{s}, 3 \mathrm{H}, \mathrm{CH}_{3}\right), 4.31\left(\mathrm{~d}, 2 \mathrm{H}, J=6.8 \mathrm{~Hz}, \mathrm{CH}_{2}\right), 7.69(\mathrm{~s}, 1 \mathrm{H}), 7.78$ (s, 1H), $9.11(\mathrm{~s}, 1 \mathrm{H})$.

4.3. Synthesis of 4-Phenyl-4-(phenylmethylene)-5(4H)-oxazolone (4e). A mixture of benzaldehyde $(505 \mu \mathrm{L}, 5 \mathrm{mmol})$, hippuric acid $(0.98 \mathrm{~g}, 5.5 \mathrm{mmol})$, acetic anhydride $(1.6 \mathrm{~mL}$, $15 \mathrm{mmol})$, and imidazolium salt $(0.051 \mathrm{~g}, 0.25 \mathrm{mmol})$ was taken in a dry $50 \mathrm{~mL}$ flask with constant stirring. The whole mixture was stirred at $60^{\circ} \mathrm{C}$ in oil bath for appropriate time (by TLC). The filtrate was cooled to room temperature, $5 \mathrm{~mL}$ 95\% EtOH were added, and yellow solid was precipitated. The yellow solid was filtered off and washed with hot water. The crude azlactone was purified by recrystallisation from acetone/water $\left(0.934 \mathrm{~g}, 75 \%\right.$ as yellow solid). M.p. $168-169^{\circ} \mathrm{C}$ (Lit. [25] M.p. $\left.168^{\circ} \mathrm{C}\right) ;{ }^{1} \mathrm{H}$ NMR (400 MHz, $\left.\mathrm{CDCl}_{3}\right) \delta=7.27$ (s, $1 \mathrm{H},-\mathrm{CH}=)$, 7.48-7.63 (m, 6H, ArH), 8.19-8.23 (m, 4H, ArH). IR (KBr) 3420, $1793(-\mathrm{C}=\mathrm{O}), 1653,1384,1167 \mathrm{~cm}^{-1}$.
Mass $(m / z): 249,116,105,89$. See Supplementry Material available at http://dx.doi.org/10.1155/2013/ 280585.

\section{Acknowledgments}

This work was financially supported by the Young Researchers Foundation of Zhejiang Provincial Top Key Academic Discipline of Applied Chemistry and EcoDyeing \& Finishing Engineering (no. ZYG2010020) and Zhejiang Provincial Top Key Academic Discipline of Applied Chemistry and Eco-Dyeing \& Finishing Engineering (no. YR2011014).

\section{References}

[1] T. Cleary, T. Rawalpally, N. Kennedy, and F. Chavez, "Catalyzing the Erlenmeyer Plöchl reaction: organic bases versus sodium acetate," Tetrahedron Letters, vol. 51, no. 12, pp. 1533-1536, 2010.

[2] E. Etschenberg, H. Jacobi, and W. Opitz, "Use of S-benzyl3-benzylthiopropionthioate in pharmaceutical compositions," EP19810101914, 1981.

[3] M. L. Gelmi, F. Clerici, and A. Melis, “5(4H)-oxazolones. Part $\mathrm{X}$. Acid and base effects on the translactonization reaction of 4-(2-oxa-alkylidene)-5(4H)-oxazolones: new synthesis of 5-alkylidene-3-benzoylamino-2(5H)-furanones," Tetrahedron, vol. 53, no. 5, pp. 1843-1854, 1997.

[4] K. Gottwald and D. Seebach, "Ring opening with kinetic resolution of azlactones by Ti-TADDOLates," Tetrahedron, vol. 55 , no. 3, pp. 723-738, 1999.

[5] A. Avenoza, J. H. Busto, C. Cativiela, and J. M. Peregrina, "Reactivity of (Z)-4-arylidene-5(4H)-oxazolones: [4+2] cycloaddition versus [4+3] cycloaddition/nucleophilic trapping," Tetrahedron Letters, vol. 43, no. 23, pp. 4167-4170, 2002.

[6] S. Kojima, H. Ohkawa, T. Hirano et al., "Fluorescent properties of model chromophores of tyrosine- 66 substituted mutants of Aequorea green fluorescent protein (GFP)," Tetrahedron Letters, vol. 39, no. 29, pp. 5239-5242, 1998. 
[7] G. P. Aguado, A. G. Moglioni, and R. M. Ortuño, "Enantiodivergent synthesis of cyclobutyl-(Z)- $\alpha, \beta$-dehydro- $\alpha$-amino acid derivatives from (-)-cis-pinononic acid," Tetrahedron Asymmetry, vol. 14, no. 2, pp. 217-223, 2003.

[8] S. T. Marino, D. Stachurska-Buczek, D. A. Huggins et al., "Synthesis of chiral building blocks for use in drug discovery," Molecules, vol. 9, no. 6, pp. 405-426, 2004.

[9] F. Y. Zhang, W. H. Kwok, and A. S. C. Chan, "A comparison of the asymmetric hydrogenation catalyzed by rhodium complexes containing chiral ligands with a binaphthyl unit and those with a 5,5',6,6 $6^{\prime}, 7,7^{\prime}, 8,8^{\prime}$-octahydro-binaphthyl unit," Tetrahedron Asymmetry, vol. 12, no. 16, pp. 2337-2342, 2001.

[10] E. Balzani and R. Robinson, "The preparation of certain azlactones," Chemistry and Industry, p. 191, 1954, (with sir Robert Robinson).

[11] E. Baltazzi and E. Davis, "Cyclodehydrations with complexes of sulfur trioxide. Synthesis of azlactones," Chemistry and Industry, p. 929, 1962, (with E.A. Davis).

[12] G. Boyd and P. Wright, "Cyclisation of $\alpha$-acylamino-acids in the presence of perchloric acid to give 5-oxo- $\Delta^{2}$-oxazolinium perchlorates," Journal of the Chemical Society, Perkin Transactions 1, pp. 909-913, 1972.

[13] Y. S. Rao, "Reactions in polyphosphoric acid. I. New stereospecific synthesis of the $\mathrm{E}$ isomers of 2-phenyl-4-arylmethylene-2oxazolin-5-ones," The Journal of Organic Chemistry, vol. 41, no. 4, pp. 722-725, 1976.

[14] F. Chen, K. Kuroda, and N. Benoiton, "A simple preparation of 5-oxo-4,5-dihydro-1,3-oxazoles (oxazolones)," Synthesis, no. 3, pp. 230-232, 1979.

[15] P. Shantham Rao and R. Venkatratnam, "Anhydrous zinc chloride catalysed synthesis of 2-phenyl-4-arylidene-5 $(4 \mathrm{H})$ oxazolones," Journal of Chemistry-Section B, vol. 33, no. 10, p. 984, 1994.

[16] K. A. Monk, D. Sarapa, and R. S. Mohan, "Bismuth (III) acetate: a new catalyst for preparation of azlactones via the Erlenmeyer synthesis," Synthetic Communications, vol. 30, no. 17, pp. 3167-3170, 2000.

[17] M. M. Khodaei, A. R. Khosropour, and S. J. H. Jomor, "Efficient and chemoselective conversion of aryl aldehydes to their azalactones catalysed by $\mathrm{Bi}(\mathrm{III})$ salts under solvent free conditions," Journal of Chemical Research-Part S, no. 10, pp. 638-641, 2003.

[18] S. Paul, P. Nanda, R. Gupta, and A. Loupy, "Calcium acetate catalyzed synthesis of 4-arylidene-2-phenyl-5(4H)- oxazolones under solvent-free conditions," Tetrahedron Letters, vol. 45, no. 2, pp. 425-427, 2004.

[19] F. M. Bautista, J. M. Campelo, A. Garcia, D. Luna, J. M. Marinas, and A. A. Romero, "Study on dry-media microwave azalactone synthesis on different supported KF catalysts: influence of textural and acid-base properties of supports," Journal of the Chemical Society, Perkin Transactions 2, no. 2, pp. 227-234, 2002.

[20] C. Yu, B. Zhou, W. Su, and Z. Xu, "Erlenmeyer synthesis for azlactones catalyzed by ytterbium(III) triflate under solventfree conditions," Synthetic Communications, vol. 36, no. 22, pp. 3447-3453, 2006.

[21] A. R. Khosropour, M. M. Khodaei, and S. J. H. Jomor, "A new, efficient and chemoselective one-pot protocol for synthesis of 4-arylidene-2-phenyl-5(4H)-oxazolones from aryl aldehyde bisulfite adducts promoted by $\mathrm{POCl}_{3}$," Journal of Heterocyclic Chemistry, vol. 45, no. 3, pp. 683-686, 2008.

[22] A. M. Tikdari, S. Fozooni, and H. Hamidian, "Dodecatungstophosphoric acid $\left(\mathrm{H}_{3} \mathrm{PW}_{12} \mathrm{O}_{40}\right)$, samarium and ruthenium
(III) chloride catalyzed synthesis of unsaturated 2-phenyl$5(4 \mathrm{H})$-oxazolone derivatives under solvent-free conditions," Molecules, vol. 13, no. 12, pp. 3246-3252, 2008.

[23] P. A. Conway, K. Devine, and F. Paradisi, "A simple and efficient method for the synthesis of Erlenmeyer azlactones," Tetrahedron, vol. 65, no. 15, pp. 2935-2938, 2009.

[24] F. Chavez, N. Kennedy, T. Rawalpally, R. T. Williamson, and T. Cleary, "Substituents effect on the erlenmeyer-plöchl reaction: understanding an observed process reaction time," Organic Process Research and Development, vol. 14, no. 3, pp. 579-584, 2010.

[25] T. Cleary, J. Brice, N. Kennedy, and F. Chavez, "One-pot process to Z- $\alpha$-benzoylamino-acrylic acid methyl esters via potassium phosphate-catalyzed Erlenmeyer reaction," Tetrahedron Letters, vol. 51, no. 4, pp. 625-628, 2010.

[26] M. Rostami, A. Khosropour, V. Mirkhani, M. Moghadam, S. Tangestaninejad, and I. Mohammadpoor-Baltork, "Organicinorganic hybrid polyoxometalates: efficient, heterogeneous and reusable catalysts for solvent-free synthesis of azlactones," Applied Catalysis A, vol. 397, no. 1-2, pp. 27-34, 2011.

[27] Y. Mashiro, H. Michiko, I. A. Karori, and O. Hiroyuki, "Ion conduction in zwitterionic-type moltensalts and their polymers," Journal of Materials Chemistry, vol. 11, no. 4, pp. 1057-1062, 2001.

[28] D. Kundu, R. K. Debnath, A. Majee, and A. Hajra, "Zwitterionictype molten salt-catalyzed syn-selective aza-Henry reaction: solvent-free one-pot synthesis of $\beta$-nitroamines," Tetrahedron Letters, vol. 50, no. 50, pp. 6998-7000, 2009.

[29] D. Kundu, A. Majee, and A. Hajra, "Zwitterionic-type molten salt: an efficient mild organocatalyst for synthesis of 2amidoalkyl and 2-carbamatoalkyl naphthols," Catalysis Communications, vol. 11, no. 14, pp. 1157-1159, 2010.

[30] M. R. Mani, "Synthesis and fungicidal activity of some new 2,3-dihydro-4H-benzimidazolo [3,2-b] [1,3]-thiazine-4-ones," Indian Journal of Heterocyclic Chemistry, vol. 13, no. 1, pp. 29-32, 2003.

[31] Y. C. Wang, D. Q. Shi, Z. S. Lu, and G. Y. Dai, "A convenient synthesis of 4-arylidene- 2-phenyloxazol-5-ones catalyzed by KF-alumina," Synthetic Communications, vol. 30, no. 4, pp. 707-712, 2000.

[32] D. G. Kuhn, "Insecticidal cinnamamide compounds and method for controlling insects therewith," US Patent 4659857, 1987. 

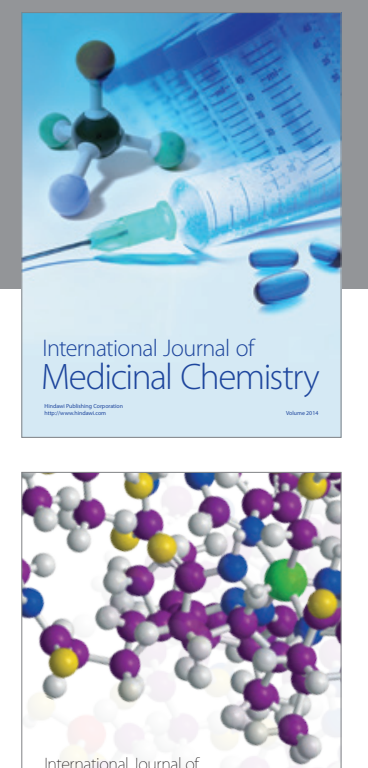

\section{Carbohydrate} Chemistry

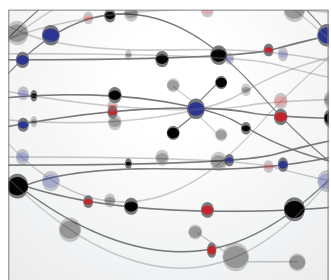

The Scientific World Journal
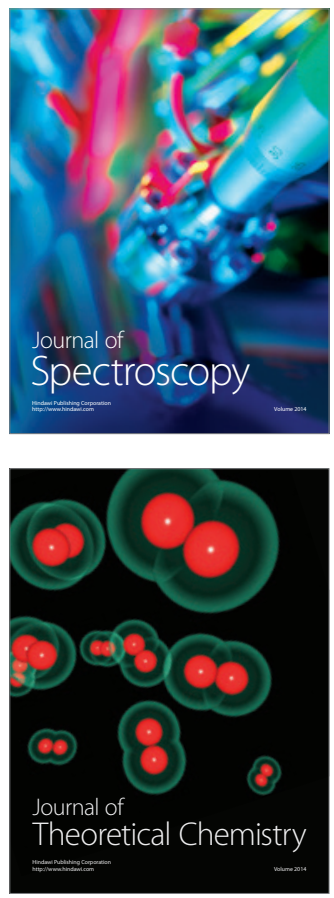
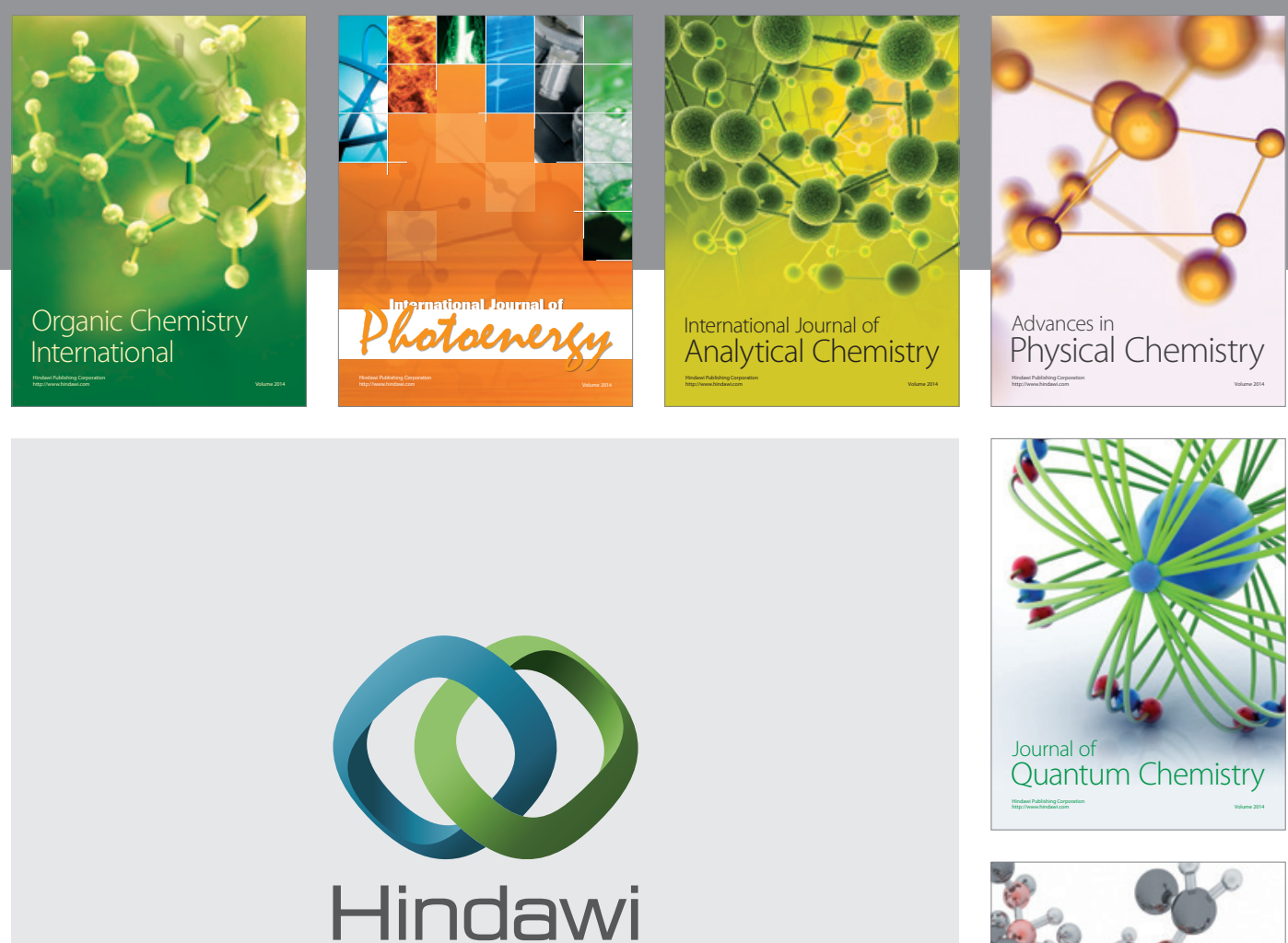

Submit your manuscripts at

http://www.hindawi.com

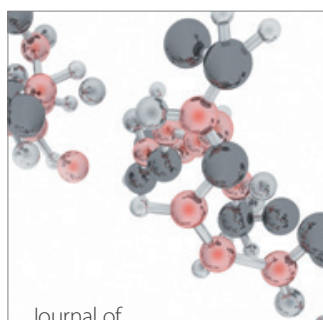

Analytical Methods

in Chemistry

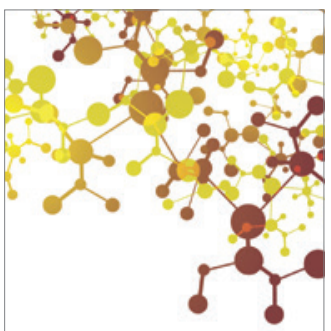

Journal of

Applied Chemistry

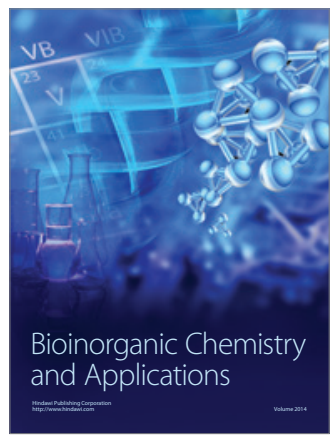

Inorganic Chemistry
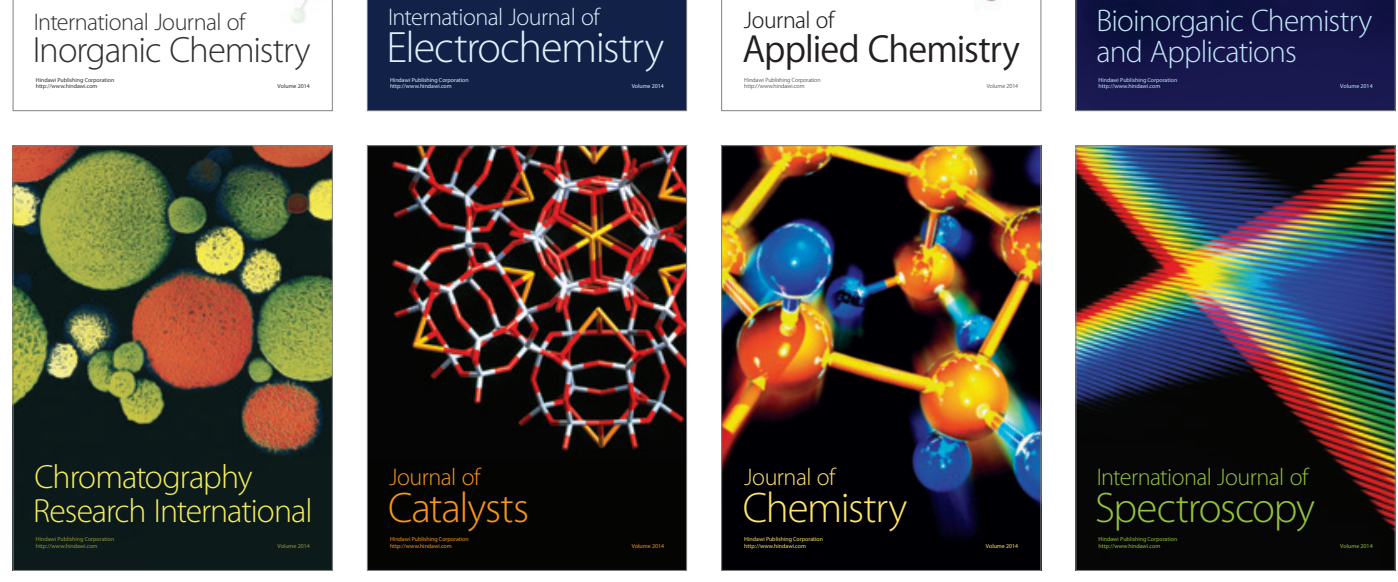